\title{
The Volta Grande do Xingu: reconstruction of past environments and forecasting of future scenarios of a unique Amazonian fluviall landscape
}

\author{
A. O. Sawakuchi ${ }^{1}$, G. A. Hartmann ${ }^{2}$, H. O. Sawakuchi ${ }^{3}$, F. N. Pupim ${ }^{1}$, D. J. Bertassoli ${ }^{1}$, M. Parra ${ }^{4}$, \\ J. L. Antinao ${ }^{5}$, L. M. Sousa ${ }^{6}$, M. H. Sabaj Pérez ${ }^{7}$, P. E. Oliveira ${ }^{1}$, R. A Santos ${ }^{1}$, J. F. Savian ${ }^{8}$, \\ C. H. Grohmann ${ }^{4}$, V. B. Medeiros ${ }^{1}$, M. M. McGlue ${ }^{9}$, D. C. Bicudo ${ }^{10}$, and S. B. Faustino ${ }^{10}$ \\ ${ }^{1}$ Institute of Geosciences, University of São Paulo, Rua do Lago, 562, São Paulo, SP, 05508-080, Brazil \\ ${ }^{2}$ Coordination of Geophysics, National Observatory, Rua General José Cristino, 77, \\ Rio de Janeiro, RJ, 20921-400, Brazil \\ ${ }^{3}$ Environmental Analysis and Geoprocessing Laboratory, Center for Nuclear Energy in Agriculture, \\ University of São Paulo, Av. Centenário, 303, Piracicaba, SP, 13400-970, Brazil \\ ${ }^{4}$ Institute of Energy and Environment, University of São Paulo, Av. Prof. Luciano Gualberto 1289, \\ São Paulo, SP, 05508-010, Brazil \\ ${ }^{5}$ Desert Research Institute, Division of Earth and Ecosystems Sciences, 2215 Raggio Parkway, \\ Reno, NV 89512, USA \\ ${ }^{6}$ Federal University of Pará, Campus de Altamira, Rua Coronel José Porfírio, 2514, \\ Altamira, PA, 68372-040, Brazil \\ ${ }^{7}$ The Academy of Natural Sciences, 1900 Benjamin Franklin Parkway, Philadelphia, PA 19103, USA \\ ${ }^{8}$ Institute of Geosciences, Federal University of Rio Grande do Sul. Avenida Bento Gonçalves, 9500, \\ Porto Alegre, RS, 91501-970, Brazil \\ ${ }^{9}$ Department of Earth and Environmental Sciences, University of Kentucky, Lexington, KY 40506, USA \\ ${ }^{10}$ Department of Ecology, Instituto de Botânica, SMA. Av. Miguel Stéfano, 3687,
} São Paulo, SP, 04301-012, Brazil

Correspondence to: A. O. Sawakuchi (andreos@usp.br)

Received: 26 August 2015 - Revised: 6 November 2015 - Accepted: 15 November 2015 - Published: 17 December 2015

Abstract. The Xingu River is a large clearwater river in eastern Amazonia and its downstream sector, known as the Volta Grande do Xingu ("Xingu Great Bend"), is a unique fluvial landscape that plays an important role in the biodiversity, biogeochemistry and prehistoric and historic peopling of Amazonia. The sedimentary dynamics of the Xingu River in the Volta Grande and its downstream sector will be shifted in the next few years due to the construction of dams associated with the Belo Monte hydropower project. Impacts on river biodiversity and carbon cycling are anticipated, especially due to likely changes in sedimentation and riverbed characteristics. This research project aims to define the geological and climate factors responsible for the development of the Volta Grande landscape and to track its environmental changes during the Holocene, using the modern system as a reference. In this context, sediment cores, riverbed rock and sediment samples and greenhouse gas (GHG) samples were collected in the Volta Grande do Xingu and adjacent upstream and downstream sectors. The reconstruction of past conditions in the Volta Grande is necessary for forecasting future scenarios and defining biodiversity conservation strategies under the operation of Belo Monte dams. This paper describes the scientific questions of the project and the sampling surveys performed by an international team of Earth scientists and biologists during the dry seasons of 2013 and 2014. Preliminary results are presented and a future workshop is planned to integrate results, present data to the scientific community and discuss possibilities for deeper drilling in the Xingu ria to extend the sedimentary record of the Volta Grande do Xingu. 


\section{Introduction}

The Xingu River is the third largest tributary of the Amazon River and the second largest clearwater river system in South America. Its downstream reach comprises an anomalous bedrock anastomozing system (Wohl and Merritt, 2001) known as the Volta Grande do Xingu ("Xingu Great Bend"). The channel morphology of the Xingu River in the Volta Grande is characterized by multiple flow-path channels with rapids flowing over fractured basement rocks. The tremendous size and morphological complexity of the rapids, combined with a high variation in water level between the dry and wet seasons, make the Volta Grande do Xingu a unique environment for Amazonian biodiversity (Zuanon, 1999; Camargo et al., 2004; Acselrad et al., 2009; Camargo and Ghilardi, 2009; Nogueira et al., 2010). Compared to other Amazonian rivers, the Xingu River also stands out due to its relatively high spatial and temporal variability in methane emissions (Sawakuchi et al., 2014) and changes in land use as a result of historic and prehistoric settlements (Heckenberger et al., 2003).

The main channel of the Volta Grande has been impounded and will be partially diverted for operation of the Belo Monte hydropower plant (Fearnside, 2006; Sousa and Reid, 2010; Sabaj Pérez, 2015), its construction expected to be complete during the second half of 2016. That project has prompted great debate surrounding the tradeoffs between energy generation and socioenvironmental impacts. The seasonal water level variation and flood pulse in the Volta Grande do Xingu will be determined by the dam's operation and energy production. Changes in river substrate and loss of environmental diversity are expected under the Belo Monte scenario. The trapping of sediments upstream and decrease in the water flow downstream of the impoundment dam will negatively affect biodiversity through the loss of various river substrates and benthic habitats. The trapping of fine-grained sediment in the in-stream and off-stream reservoirs can stimulate the production of greenhouse gases (GHG). The shift from bedrock/sand to mud substrates is expected to increase GHG emissions, based on comparisons of $\mathrm{CH}_{4}$ emissions from the Xingu rapids and the ria sectors (Sawakuchi et al., 2014). Also, agricultural activities have increased deforestation rates in the Xingu River catchment during recent decades, which will favor runoff and will improve hydropower generation in the short term, but may reduce hydropower potential in the long term as a result of lower precipitation throughout the catchment (Stickler et al., 2013). The possible negative feedback response of the lower Xingu to deforestation and hydropower projects requires urgent attention. Reconstruction of past hydrology, sediment supply, vegetation and ecological conditions in the Xingu catchment is critical to evaluate the long-term state and sensitivity of the Xingu River and analogous clear waters such as the Tapa- jós and Tocantins rivers, especially in the context of global climate change and regional anthropogenic disturbance. The characterization of past changes in vegetation and sedimentation rates allows one to track drought and flood events and their impacts on the Volta Grande ecosystem. Understanding changes in river substrate induced by anthropogenic or natural changes in hydrology is important because riverbed characteristics play a key role in aquatic ecology and GHG production.

This project comprises a multidisciplinary research team working to improve knowledge on the origin of the Volta Grande do Xingu, the reconstruction of its Late Quaternary changes in vegetation, hydrology and biogeochemistry, and related effects on biodiversity. Additionally, we expect that a better understanding of the fluvial dynamics of the Volta Grande do Xingu on scales from hundreds to thousands of years before present will yield valuable insights to forecast future environmental scenarios. The Belo Monte Dam complex will directly affect the Volta Grande by flooding approximately $382 \mathrm{~km}^{2}$ over an 80 river $\mathrm{km}$ stretch of the Xingu channel, and dewatering another 90 river km below the impoundment dam with a reduction in flood pulse magnitude and variability (Sabaj Pérez, 2015). Tracking past changes in the Xingu River flow will establish natural baselines to evaluate future environmental changes due to the Belo Monte. In this context, sediment cores were collected in the Xingu ria and floodplain lakes of the Volta Grande. Riverbed rock and sediment samples and GHGs emitted from the river channel and areas that will be flooded by the Belo Monte dams were collected to characterize the Volta Grande do Xingu before the dam's operation. This report presents the questions that motivated the project, the location and characteristics of sediment cores, and preliminary data obtained after sampling.

\section{Site description}

The Xingu is an Amazonian clearwater river (Sioli, 1985), with a bedload dominated by fine to coarse sand, low suspended load and neutral to slightly alkaline waters ( $\mathrm{pH}$ approximately 7.3). After the confluence with the Iriri River, the Xingu flows NE and bends $90^{\circ}$ at the transition between the Amazon craton basement and the Amazon sedimentary basin (Fig. 1). After flowing to the SE for around $60 \mathrm{~km}$, the Xingu bends $90^{\circ}$ again to the NE. It continues to flow over basement rocks for another $60 \mathrm{~km}$ until its last $90^{\circ}$ bend, where it crosses the sedimentary rocks at the border of the Amazon basin. Those three sequential $90^{\circ}$ bends form the Volta Grande do Xingu and compose an exceptionally complex planform that is unique among large tropical rivers. In this sector, the Xingu is a bedrock river characterized by a 4 $5 \mathrm{~km}$ wide channel segmented into multiple interconnected crisscross channels with rapids bounding sediment bars covered by riparian vegetation and rainforest. The origin of 

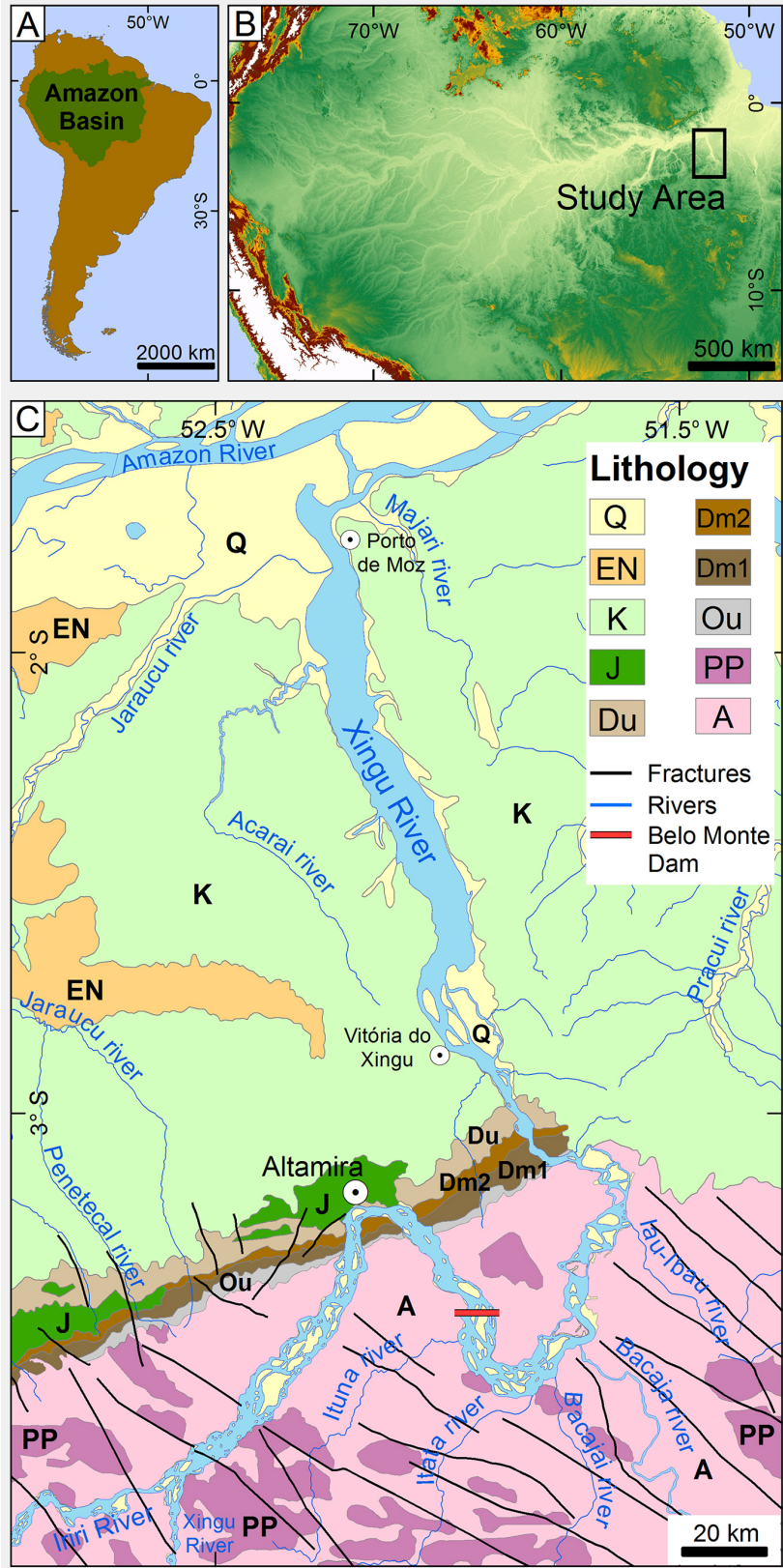

Figure 1. Simplified geological map of the Volta Grande do Xingu and Xingu ria, eastern Amazonia (Bahia et al., 2004). Lithologies: (A) Archean gneisses, granodiorites and granitoids (Xingu complex) and metavolcanic and metasedimentary rocks; (PP) intrusive suites: Paleoproterozoic granites, granodiorites and charnockites; (Ou) Ordovician-Devonian organic-rich shales and sandstones (Trombetas group); (Dm1-Dm2-Du) Middle-Upper Devonian shales, siltstones and sandstones (Urupadi and Curuá groups); (J) Triassic-Jurassic diabase (Penatecaua formation); (K) Alter do Chão formation: sandstones and conglomerates; (EN) EoceneNeogene undifferentiated sediments and laterite crusts; (Q) undifferentiated Quaternary sediments. The red bar indicates the position of the main Belo Monte dam (Pimental site).
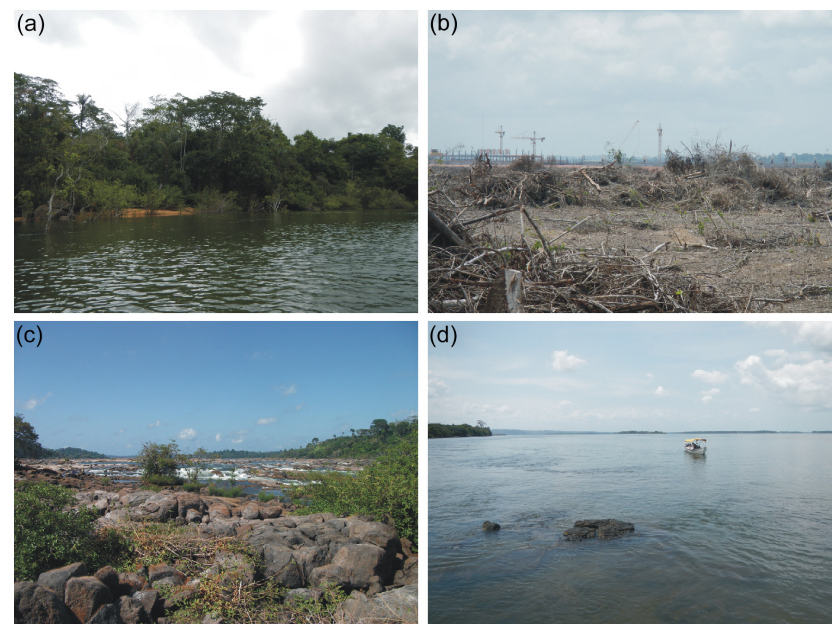

(d)

Figure 2. (a) Stabilized sediment bar (island) covered by forest vegetation nearby the Pimental dam site. (b) Deforested sediment bar to be flooded by the Belo Monte reservoir. Picture from island adjacent (upstream) to the Pimental dam site. (c) Rapids in the downstream sector of the Volta Grande. (d) Xingu ria downstream of the Volta Grande. Pictures taken during the dry season (November 2014).

this particular channel morphology is still under debate. The Xingu flows as a bedrock-dominated river until it enters the Amazon sedimentary basin through a singular channel about $0.5 \mathrm{~km}$ wide at its narrowest point and up to $80 \mathrm{~m}$ deep (Sabaj Pérez, 2015). At the transition, it suddenly drops from elevations of 60-90 to 5-20 m and shifts to a lowland Amazonian river with a single slack water channel under the influence of tides (the "Xingu ria"). The Xingu ria channel can reach up to $14 \mathrm{~km}$ in width, flowing straight for about $180 \mathrm{~km}$ until it reaches the Amazon River. The upstream sector of the Xingu ria is occupied by a complex of stabilized bars, the Tabuleiro do Embaubal archipelago, which is formed by the trapping of sands that bypass the Volta Grande. Figure 2 shows some fluvial landscapes characterizing the Xingu River within the studied sector.

\section{Scientific questions}

This project deals with the characterization of the present sedimentary dynamics and reconstruction of past environmental conditions of the Volta Grande during the Quaternary. The description of the present state of the Volta Grande will provide a reference scenario to track past environmental changes. It is also a fundamental exercise to evaluate future changes due to the Belo Monte Dam complex. The reconstruction of paleogeography, paleovegetation and paleohydrology will shed light on how the Volta Grande do Xingu achieved its present geomorphological and ecological complexity, allowing us to evaluate the long-term variability of 
river dynamics. The main scientific questions motivating this project are the following.

A. What is the age of the rapids of the Volta Grande? The rapids of the Volta Grande do Xingu play a major role in aquatic diversity and endemism, particularly for fishes. The uplift and exhumation histories of the bedrock channels will be studied at multiple timescales through cosmogenic nuclides $\left({ }^{10} \mathrm{Be}\right)$ measured in sediments and bedrock and (U-Th)/He and fission track thermochronometry in apatite retrieved from basement samples in the Volta Grande and from dikes and sills cutting through sedimentary rocks farther to the north, in the Amazon sedimentary basin domain. Surface exposure ages of rapids and waterfalls, as well as catchment erosion rates, will be determined through ${ }^{10} \mathrm{Be}$ measurements. Thermochronometry techniques will reveal the age and rates of rock exhumation from depths less than 1-4 km. By comparing differences in exhumation rates in different localities, a minimum age for potential differential uplift along the Volta Grande will be constrained. This information is a critical step towards assessing how and when the Volta Grande achieved its rich and endemic diversity of rheophilic fishes and other aquatic organisms.

B. What effect did Quaternary precipitation changes have on river sediment supply? Changes in sediment composition and sedimentation rate through time will be compared with the precipitation changes in the South American Monsoon System (SAMS). This will allow us to evaluate the response of fluvio-hydrological variables such as water turbidity and river level seasonality to Quaternary climate changes. Age models to constrain environmental indicators (e.g., geochemistry, environmental magnetism) will be supported by ${ }^{14} \mathrm{C}$ and optically stimulated luminescence (OSL) dating. The reconstruction of the sediment supply through time also affords insights into shifts in channel morphology, especially with regards to the building and erosion of sediment bars covering bedrock within the rapids.

C. How did riparian vegetation respond to Holocene climatic and anthropogenic changes? Various palynological studies carried out in Amazonia suggest that during the Late Holocene, drought episodes and human interference in the landscape were non-uniform in time and space, suggesting that the period may have been unusually dynamic with respect to climate (Bush et al., 2014). Other studies also point to evidence of increase in frequency of anthropogenic and climate-related fires, with significant changes in vegetation (McMichael et al., 2012a, b). Archaeological evidence suggests that human settlement of the Xingu River catchment dates to the Middle Holocene (e.g., Silva and Rebellato, 2003). Terra Preta de Índio, pottery and petroglyphs are widespread along river banks of the Xingu, including the Volta Grande site. Changes in land use for agriculture and mining activities have intensified in the Xingu catchment during the last several decades. Thus, the history of human occupation of eastern Amazonia and changes in vegetation induced by anthropogenic activities over the last decades to few millennia could be recorded in sediments from floodplain lakes and from the Xingu ria. We expect to generate a high-resolution record of paleovegetation and sedimentation rates for tracking of decadal to millennial anthropogenic and climate changes in the Xingu River catchment.

D. How do the carbon budget and GHG emissions respond to changes in sediment supply and river level? Riverbed sediment type, suspended sediment concentration and changes in water depth throughout the year can drastically influence GHG emissions from Amazonian rivers. The lower Xingu River (ria sector) has the greatest $\mathrm{CH}_{4}$ flux among the main Amazon River tributaries (Sawakuchi et al., 2014). Thus, a significant share of the $\mathrm{CH}_{4}$ flux from the future reservoirs might be attributed to the previous natural river emission, compensating for the emission from impounded water to some extent. On the other hand, bacteria in oxic soils tend to consume atmospheric $\mathrm{CH}_{4}$, and after flooding those soils become an important hotspot of $\mathrm{CH}_{4}$ production fueling the reservoir. Although hydroelectric reservoirs generally have lower carbon emission per energy production than thermal energy supply (Ometto et al., 2013), such reservoirs are far from neutral for GHG emissions (Almeida et al., 2013). Nevertheless, most of the available information regarding $\mathrm{GHG}$ emissions from reservoirs does not take into account the natural emissions of GHG from the running river and soil consumption before flooding. $\mathrm{CH}_{4}$ and $\mathrm{CO}_{2}$ flux measurements from rivers and soil in areas directly affected by the Belo Monte reservoirs, before impoundment, were performed to serve as a baseline to track future changes in fluxes caused by the reservoirs. The Xingu ria is considered a depositional system analogous to the Belo Monte hydroelectric reservoirs. In this way, $\mathrm{CH}_{4}$ production and flux within muddy sediments from the Xingu ria are well suited to inform decadal to millennial changes in GHG emissions and carbon budget due to changes in the water column and riverbed. Deposition rates, carbon concentration and GHG concentrations measured in sediment cores of the ria sector provide constraint values on how substrate changes in the reservoirs will affect carbon sink and GHG production and emission over decadal to millennial timescales. 

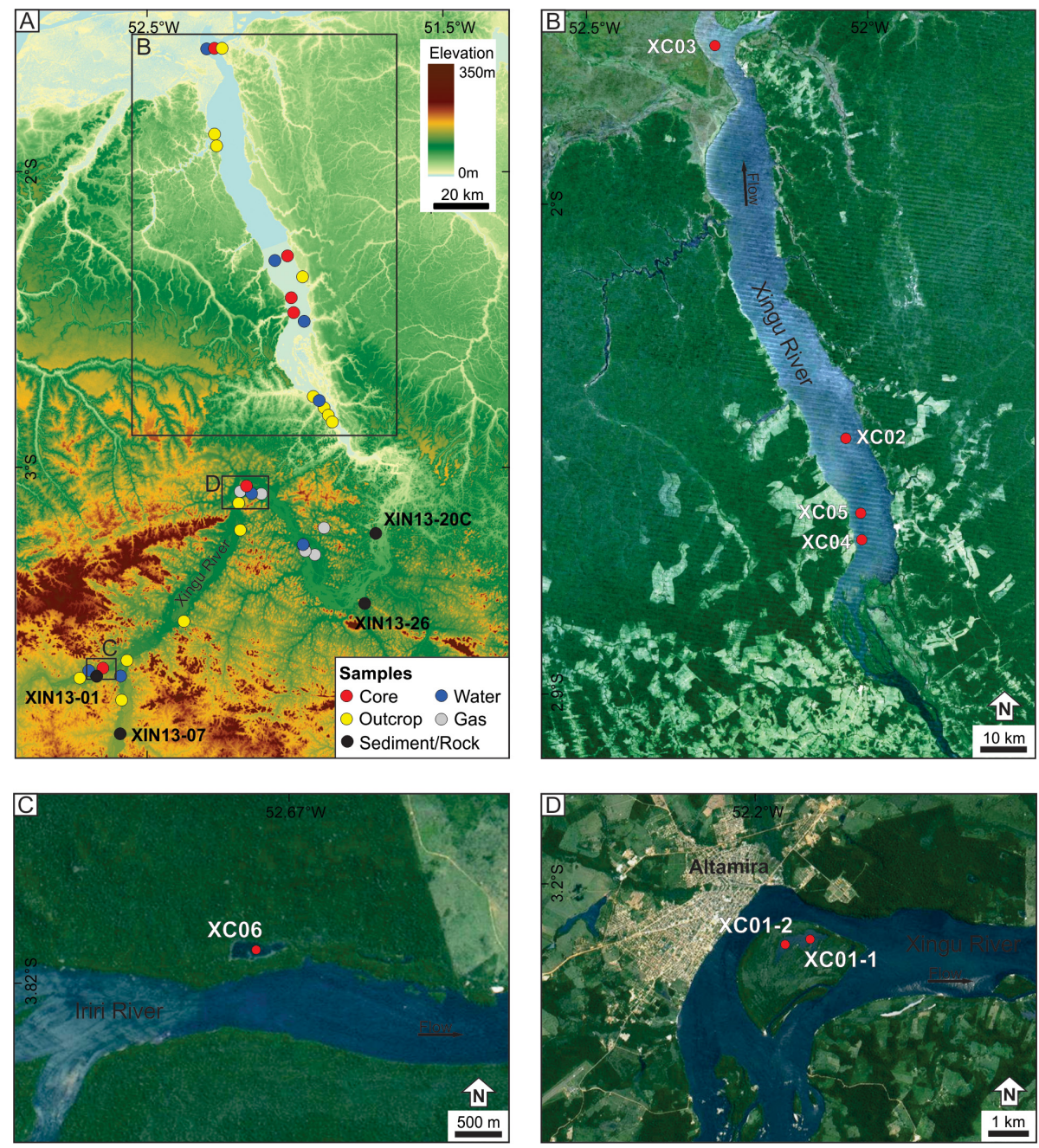

Figure 3. (a) Location of sediment cores (XC01 to XC06), surface sediments, rock and gas samples retrieved in the Volta Grande do Xingu and the Xingu ria. Elevation data from SRTM. (b, c, d) Sediment cores were collected in the ria and floodplain lakes. Satellite images from Google Earth.

\section{Sampling of sediment cores, riverbed rocks and greenhouse gases}

Field surveys were performed during the dry seasons of 2013 and 2014. Sites for coring in the Xingu ria were selected based on water depth profiles coupled with riverbed sediment sampling. Cores were collected in deeper portions of the channel covered by muddy sediments. Deeper zones of perennial floodplain lakes and the Xingu ria were the targets for coring, since they represent accumulation sites characterized by relatively continuous deposition of fine-grained sediments throughout the year. Eight sediment cores were retrieved from the Xingu ria and from nearby floodplain lakes. Sediment cores were collected in water depths from $1 \mathrm{~m}$ (floodplain lakes) to $18 \mathrm{~m}$ (ria), the latter depths (ria) by divers. The cores were collected using PVC tubes of up to $6 \mathrm{~m}$ in length and percussion into the substrate. Samples of riverbed bedrock surfaces and sands were collected in rapids and waterfalls for determination of surface exposure ages, erosion rates and basement cooling and exhumation history. Parallel surveys by a team of ichthyologists will allow us to evaluate ecological relationships between fishes and riverbed characteristics. Floating chambers were used to measure $\mathrm{CO}_{2}$ and $\mathrm{CH}_{4}$ fluxes from the river channel and water samples were used to analyze gas concentration and stable carbon isotope ratio via headspace extraction (Sawakuchi et al., 2014). Static chambers were used to measure $\mathrm{CO}_{2}$ and $\mathrm{CH}_{4}$ fluxes from soil to atmosphere on stabilized bars and along river margins that will be flooded by the Belo Monte reservoir. Figure 3 shows the locations of sediment cores and surface sediment, rock and gas samples. Table 1 lists the water depth, retrieved sediment column and geographical coordinates of each sediment core. 
Table 1. Sediment cores retrieved in the Xingu ria and floodplain lakes of the Xingu and Iriri rivers.

\begin{tabular}{llcccc}
\hline Setting & Core code & $\begin{array}{c}\text { Water depth } \\
(\mathrm{m})\end{array}$ & $\begin{array}{c}\text { Retrieved sediment } \\
\text { thickness }(\mathrm{cm})\end{array}$ & $\begin{array}{c}\text { Latitude } \\
(\text { deg. })\end{array}$ & $\begin{array}{c}\text { Longitude } \\
(\text { deg. })\end{array}$ \\
\hline Xingu floodplain lake & XC01-1 & 1 & 200 & -3.214142 & -52.188714 \\
& XC01-2 & 1 & 120 & -3.214277 & -52.190118 \\
Xingu ria & XC02-1 & 13 & 300 & -2.412991 & -52.027668 \\
& XC03 & 10 & 370 & -1.708922 & -52.279840 \\
& XC04 & 18 & 516 & -2.604619 & -52.012447 \\
Iriri floodplain lake & XC05 & 13 & 470 & -2.556209 & -52.016087 \\
& XC06 & 1.5 & 230 & -3.816163 & -52.672267 \\
\hline
\end{tabular}

\section{Project development}

\subsection{Cosmogenic nuclides and landscape evolution}

Sampled sediments from lateral bars in the Volta Grande (Fig. 3a) that were targeted for cosmogenic ${ }^{10} \mathrm{Be}$ analysis of catchment-wide average erosion rates were processed at the Desert Research Institute (quartz purification) and Dalhousie University (extraction of Be target material for AMS (accelerator mass spectrometry) as $\mathrm{BeO}$ ) in 2014, following protocols adapted from Kohl and Nishiizumi (1992). $\mathrm{BeO}$ targets extracted from the samples were analyzed by ${ }^{10} \mathrm{Be} /{ }^{9} \mathrm{Be}$ ratios at Lawrence Livermore National Laboratory. Estimated values for catchment-wide ${ }^{10} \mathrm{Be}$ production rates were calculated from averaging individual production obtained pixel-by-pixel and scaled by altitude in a $1 \mathrm{~km}$ DEM for the catchment above the sampling point (Table 2). We are currently refining that estimate by considering shielding by topography, but given the low relief of the area, it should not change the results by more than 1-2\%. Volta Grande denudation rates are of a similar order of magnitude compared to rates recorded for the Xingu further upstream, near São José do Xingu (the latter as published by Wittmann et al., 2011, and also based on recalculated rates using recent ${ }^{10} \mathrm{Be}$ production rate estimates; those values are shown in Table 2). Denudation rates along the Xingu main stem are $50 \%$ higher than those from the tributaries (Iriri and Bacajaí rivers). We interpret the lower denudation rates for the Xingu tributaries as indicative of a stable landscape during the Late Pleistocene-Holocene for the specific region in the immediate vicinity of the Volta Grande. The apparent age or averaging period (von Blanckenburg, 2005) derived from the Iriri and Bacajaí samples is 70-100 ka (Table 2). The homogeneous and low $\left(0.01 \mathrm{~mm} \mathrm{a}^{-1}\right)$ denudation rates indicate that differences in landscape activity between the catchment upstream of Sao José do Xingu (Wittman et al., 2011) and upstream of the Volta Grande are not significant and that the present-day landscape configuration at the catchment scale probably has an age of several tens of thousands of years. A better understanding of denudation along outcrops in the Xingu main stem nevertheless will be given by bedrock samples that were taken at two different strath levels above the river level. Those two levels were sampled at different elevations above the main flow surface (i.e., relative to the 2013 September low stage flow) and at different points along the river. Analyses are still in progress and final AMS measurements will be performed following preparation of samples with an improved low ${ }^{10} \mathrm{Be} /{ }^{9} \mathrm{Be}$ ratio carrier at the Desert Research Institute during 2015. The results will help us to further check whether the landscape as a whole is relatively old (similar, high ${ }^{10} \mathrm{Be}$ concentrations on both landscape and bedrock surfaces, suggesting saturation; cf. Lal, 1991) or whether younger surfaces appear in certain landscape positions showing recently abraded or plucked bedrock portions at lower ${ }^{10} \mathrm{Be}$ concentrations (Fujioka et al., 2015). If ${ }^{10} \mathrm{Be}$ bedrock concentrations are low enough (i.e., an order of magnitude less than overall sand concentrations), we will attempt to measure in situ cosmogenic ${ }^{14} \mathrm{C}$ in the quartz we have already purified. This will allow for the analysis of potentially young (i.e., Late Quaternary) erosion events in the main stem via a paired isotope study (e.g., Hippe et al., 2014). It must be noted that the ${ }^{10} \mathrm{Be}$ bedrock study by itself does not intend to provide direct ages for bedrock exposure, but rather acts as a guide to implement subsequent tests. An apatite fission track and (U-Th)/He thermochronology will be used to constrain older landscape evolution events recorded in the Volta Grande.

\subsection{Fish diversity and riverbed complexity}

The morphology and composition of Xingu River substrates are extremely important for aquatic ecology and biodiversity. The Volta Grande is dominated by substrates consisting of fractured bedrocks, iron oxide crusts, gravels and sands. Iron oxide crusts allow for the formation of complex morphologies in the riverbed. The Xingu ria has a more homogeneous riverbed mainly covered by organic-rich mud, with sand deposition in the ria head and on the shallow marginal portions of the channel. The substrate complexity in the Volta Grande offers more niche space, and is hypothesized to be a driver of diversity among rheophilic fishes in the Volta Grande compared to the Xingu ria. An old and stable system of clearwater and complex braids with rocky rapids might account for the exceptionally diverse fish fauna, especially with respect 
Table 2. Fluvial sand ${ }^{10} \mathrm{Be}$ concentration and calculated catchment-wide average denudation rates for catchments above sampling points in the Xingu River and the Iriri and Bacajaí tributaries. Production rates obtained by averaging pixel-by-pixel the production rates calculated according to the Lal (1991) and Stone (2000) scaling scheme, using the global production rate in Heyman (2014). Full data set given only for samples measured in this study. For comparison of final results, we also present the final ${ }^{10} \mathrm{Be}$ data by Wittmann et al. (2011). AMS ${ }^{10} \mathrm{Be} /{ }^{9} \mathrm{Be}$ ratio for the blank: $2.019 \pm 0.425 \times 10^{-15}$. Standard used for normalization 07KNSTD3110, with a ${ }^{10} \mathrm{Be} /{ }^{9} \mathrm{Be}$ ratio of $2.85 \times 10^{-12}$. Samples measured after adding a Be carrier solution of density $1.013 \mathrm{~g} \mathrm{~mL}^{-1}$, at a concentration of $282 \mathrm{ppm}$ Be. Carrier added to blank: $0.825 \mathrm{~g}$.

\begin{tabular}{|c|c|c|c|c|c|c|c|c|c|}
\hline $\begin{array}{l}\text { Sample location, } \\
\text { sample ID } \\
\text { (Lat/long) }\end{array}$ & $\begin{array}{l}\text { Grain size } \\
\qquad(\mu \mathrm{m})\end{array}$ & $\begin{array}{c}\text { Measured AMS } \\
{ }^{10} \mathrm{Be} /{ }^{9} \mathrm{Be} \\
\text { ratio }\left(10^{-13}\right)\end{array}$ & $\begin{array}{l}\mathrm{Be} \\
\text { carrier } \\
(\mathrm{g})\end{array}$ & $\begin{array}{l}{ }^{10} \text { Be concentration } \\
\left(10^{5} \text { atom } \mathrm{g}^{-1}\right)\end{array}$ & $\begin{array}{l}\text { Latitude } \\
\text { (deg) }\end{array}$ & $\begin{array}{l}\text { Longitude } \\
\text { (deg) }\end{array}$ & $\begin{array}{l}\text { Average production } \\
\text { rate }\left(\text { atom } \mathrm{g}^{-1} \mathrm{y}^{-1}\right)\end{array}$ & $\begin{array}{l}\text { Denudation rate } \\
\left(10^{-3} \mathrm{~mm} \mathrm{y}^{-1}\right)\end{array}$ & $\begin{array}{l}\text { Apparent } \\
\text { (ky) age }\end{array}$ \\
\hline $\begin{array}{l}\text { Iriri before Xingu } \\
(\mathrm{XIN} 13-01)\end{array}$ & $250-710$ & $4.8 \pm 0.09$ & 0.828 & $2.42 \pm 0.07$ & -3.823547 & -52.677468 & $3.2 \pm 0.2$ & $8.49 \pm 0.08$ & 70.6 \\
\hline $\begin{array}{l}\text { Xingu before Iriri } \\
\text { (XIN13-07) }\end{array}$ & $250-710$ & $3.6 \pm 0.06$ & 0.822 & $1.78 \pm 0.05$ & -4.038006 & -52.594669 & $3.6 \pm 0.2$ & $13.2 \pm 1.26$ & 45.6 \\
\hline $\begin{array}{l}\text { Xingu downstream } \\
\text { Bacajaí (XIN13-20C) }\end{array}$ & $250-710$ & $4.2 \pm 0.08$ & 0.824 & $2.1 \pm 0.06$ & -3.362553 & -51.733718 & $3.5 \pm 0.2$ & $10.7 \pm 1.0$ & 55.9 \\
\hline $\begin{array}{l}\text { Bacajaí } \\
\text { (XIN13-26) }\end{array}$ & $250-710$ & $6.9 \pm 0.13$ & 0.818 & $3.45 \pm 0.095$ & -3.588783 & -51.763820 & $3.03 \pm 0.2$ & $6 \pm 0.57$ & 108.7 \\
\hline $\begin{array}{l}\text { Wittmann et al. (2011) } \\
\text { sample location }\end{array}$ & & & & & & & & $\begin{array}{l}\text { (Value } \\
\text { recalculated) }\end{array}$ & \\
\hline $\begin{array}{l}\text { Xingu near São José } \\
\text { do Xingu }\end{array}$ & $125-250$ & - & - & $2.55 \pm 0.19$ & -10.763321 & -53.099340 & $5.1 \pm 0.3$ & $13 \pm 1.2$ & 46.1 \\
\hline $\begin{array}{l}\text { Xingu near São José } \\
\text { do Xingu }\end{array}$ & $250-500$ & - & - & $2.32 \pm 0.19$ & -10.763321 & -53.099340 & $5.1 \pm 0.3$ & $14 \pm 1.3$ & 42.0 \\
\hline $\begin{array}{l}\text { Xingu near São José } \\
\text { do Xingu }\end{array}$ & $250-500$ & - & - & $2.25 \pm 0.96$ & -10.763321 & -53.099340 & $5.1 \pm 0.3$ & $15 \pm 1.4$ & 40.5 \\
\hline
\end{tabular}

to lithophilic and rheophilic species like loricarid catfishes (Fig. 4). Furthermore, the clarity of the water may enhance the effects of substrate composition and coloration on the color patterns of fishes, especially lithophilic species. Thus, the concentration of suspended sediments and its variation due to changes in hydrology and vegetation cover may play an important role in fish evolution and ecology. Changes in riverbed complexity and fish diversity will be monitored during operation of Belo Monte dams. Digital elevation models (DEMs) such as SRTM (Farr et al., 2007) and ASTER GDEM (Tachikawa et al., 2011) and bathymetric surveys will provide information for morphometric analysis (Grohmann, 2004; Grohmann et al., 2007) of the Volta Grande region and correlation with niche segregation among fishes.

\subsection{Core description and sampling}

To date, two sediment cores (XC01-2 and XC05) have been opened for description and sub-sampling. Sediment core XC01-2 was collected in a floodplain lake under $1 \mathrm{~m}$ water depth, and it consists of $\sim 123 \mathrm{~cm}$ of sediments (Table 1). The lowermost portion $(123-78 \mathrm{~cm})$ presents medium to coarse sand with an overall fining upward pattern. Finegrained muddy sediments with colors varying from dark gray (78-29 cm) to brown $(29-0 \mathrm{~cm})$ cover the sandy unit (Fig. 5). Three samples of wood sediments for radiocarbon dating and three samples for OSL dating were retrieved from the muddy and sandy beds, respectively. The XC05 sediment core was

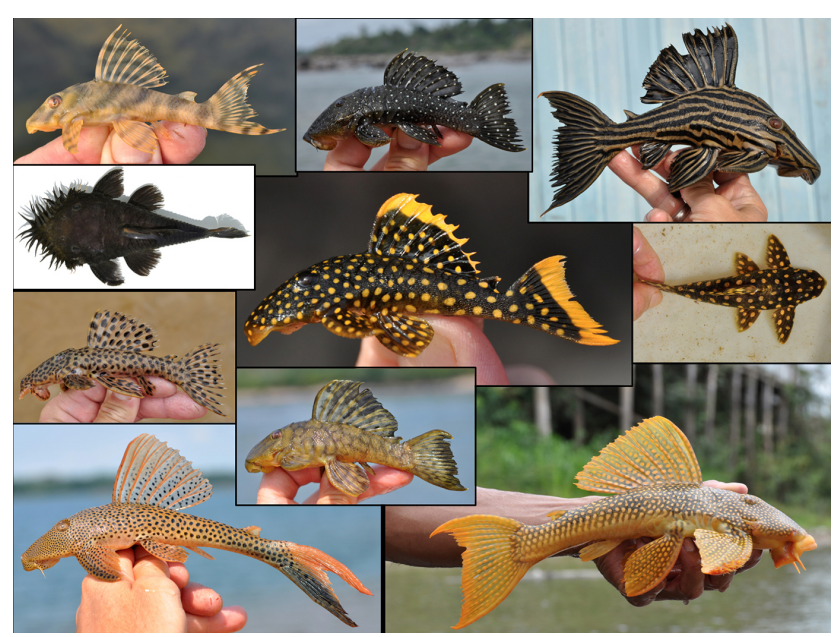

Figure 4. Diversity of sucker mouth armored catfishes (Loricariidae) in the Xingu River, with emphasis on lithophilous species. Clockwise from upper left: Peckoltia vittata, Parancistrus nudiventris, Panaque armbrusteri, Scobinancistrus sp., Scobinancistrus aureatus, Squaliforma sp., Leporacanthicus heterodon, Ancistrusranunculus. Center upper: Baryancistrus xanthellus. Center lower: Spectracanthicus zuanoni.

collected in the middle portion of the Xingu ria under a water depth of $13 \mathrm{~m}$ and comprises a sediment column of $\sim 470 \mathrm{~cm}$ (Table 1). This sediment core is characterized by dark gray to brown muds with rare fragments of plant material (Fig. 5). 

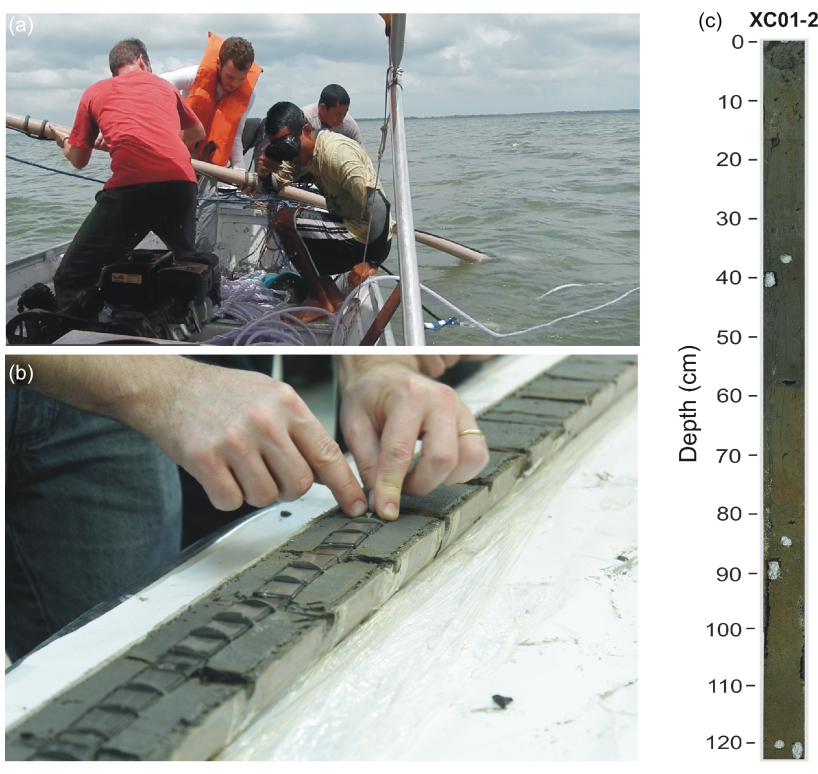

Figure 5. (a) Retrieving of the XC03 core during November of 2014. (b) Sampling of the XC05 core $(470 \mathrm{~cm})$ for magnetic analysis. This core is composed of homogenous organic muddy sediments. (c) Sediment column of the XC01-2 core, with a bottom sand layer covered by dark gray to brown muds.

Sediment samples for measurements of $\mathrm{CH}_{4}$ concentration were collected at $10 \mathrm{~cm}$ intervals immediately $(4-5 \mathrm{~h}$ ) following coring, to avoid $\mathrm{CH}_{4}$ oxidation. Samples for quartz OSL dating and for radiocarbon dating of particulate organic matter were collected at intervals of 30 to $40 \mathrm{~cm}$. Samples for pollen/spore, diatoms, magnetic minerals, and organic and inorganic sediment geochemistry analyses were collected at $2 \mathrm{~cm}$ intervals.

\subsection{OSL and ${ }^{14} \mathrm{C}$ dating}

The samples at 120 and $84 \mathrm{~cm}$ depth from core XC012 were prepared for quartz OSL dating in the Luminescence and Gamma Spectrometry Laboratory of the Institute of Geosciences of the University of São Paulo. These samples represent the sand bed (bar top) underlying muddy sediments of the floodplain lake. Equivalent doses (De) were estimated using the single-aliquot regenerative (SAR) dose protocol (Murray and Wintle, 2003) in multigrain aliquots $(180-250 \mu \mathrm{m}$ grain size). Equivalent doses were calculated using 24 aliquots per sample and the Central Age Model (Galbraith et al., 1999). Radiation dose rates were calculated through radionuclide concentrations measured using high-resolution gamma spectrometry. Samples at 120 and $84 \mathrm{~cm}$ presented sediment deposition ages of $6987 \pm 513$ years $(\mathrm{De}=5.89 \pm 0.20 \mathrm{~Gy}$; dose rate $\left.=0.843 \pm 0.055 \mathrm{~Gy} \mathrm{ka}^{-1}\right)$ and $4318 \pm 278$ years $\left(\mathrm{De}=3.58 \pm 0.10 \mathrm{~Gy}\right.$; dose rate $\left.=0.829 \pm 0.048 \mathrm{~Gy} \mathrm{ka}^{-1}\right)$, respectively. Thus, sediment core XC01-2 records sediment deposition since the Middle Holocene, with the floodplain lake established approximately $4318 \pm 278$ years ago.

\subsection{Magnetic analysis}

Environmental magnetism techniques are used to investigate the formation, transportation, and depositional and postdepositional alterations of magnetic minerals in sediments (Thompson and Oldfield, 1986; Evans and Heller, 2003). Changes in the concentration, grain size and shape of magnetic minerals are related to climate through processes affecting sediment composition and texture, such as weathering conditions, vegetation type and erosion rates in the sediment source areas.

Magnetic susceptibility measurements of core XC05 were performed at the Paleomagnetic Laboratory of the Institute of Astronomy, Geophysics and Atmospheric Sciences, University of São Paulo (IAG/USP). Paleomagnetic specimens from the XC05 sediment core were collected using cubic plastic boxes $\left(8 \mathrm{~cm}^{3}\right)$ placed side-by-side continuously with orientation to the top-bottom, totaling 194 specimens (Fig. 5b). Low-field magnetic susceptibility of each specimen was measured using a Kappabridge MFK1-FA system (AGICO Ltd) with two different frequencies of 976 and $15616 \mathrm{~Hz}$ in a $200 \mathrm{~A} \mathrm{~m}^{-1}$ field at room temperature (Dearing et al., 1996). Magnetic susceptibility values vary from $\sim 2.8 \times 10^{-8}$ to $\sim 1.8 \times 10^{-7} \mathrm{~m}^{3} \mathrm{~kg}^{-1}$ (Fig. 6). Some strong variations (peaks) may indicate variations in sedimentation rate or different magnetic minerals present in the XC05 core. Additional magnetic analyses will be applied to determine the magnetic carriers and their nature.

\section{6 $\mathrm{CH}_{4}$ production and emission}

The Xingu ria has lake-like sedimentary dynamics and thereby serves as an analogous setting for the future of Belo Monte's reservoirs. Many insights about future changes in GHG emissions can be obtained through the study of $\mathrm{CH}_{4}$ and $\mathrm{CO}_{2}$ dissolved in the water and within the sediments of the Xingu ria. To this end, we measured natural emissions of GHG and collected gas samples extracted from pore water of the $\mathrm{XC05}$ core to evaluate the effect of sediment texture and composition on the production and flux of $\mathrm{CH}_{4}$ and $\mathrm{CO}_{2}$. $\mathrm{CH}_{4}$ and $\mathrm{CO}_{2}$ flux measurements from rivers were performed according to Sawakuchi et al. (2014) using simultaneously five floating chambers. At the same time, surface waters were collected to determine gas concentration in the water after headspace extraction. Dissolved gas concentration was calculated using Henry's law adjusted for temperature (Wiesenburg and Guinasso, 1979). Fluxes from soils were measured using static chambers and procedures similar to the used by Neu et al. (2011). Gas samples were analyzed on a Picarro Cavity Ring Down Spectroscopy Analyzer (model G2201i). The $\mathrm{CH}_{4}$ concentration in pore waters from the $\mathrm{XC05}$ core ranged from 0.1 to $24.5 \%$ (Fig. 6). The stable carbon 


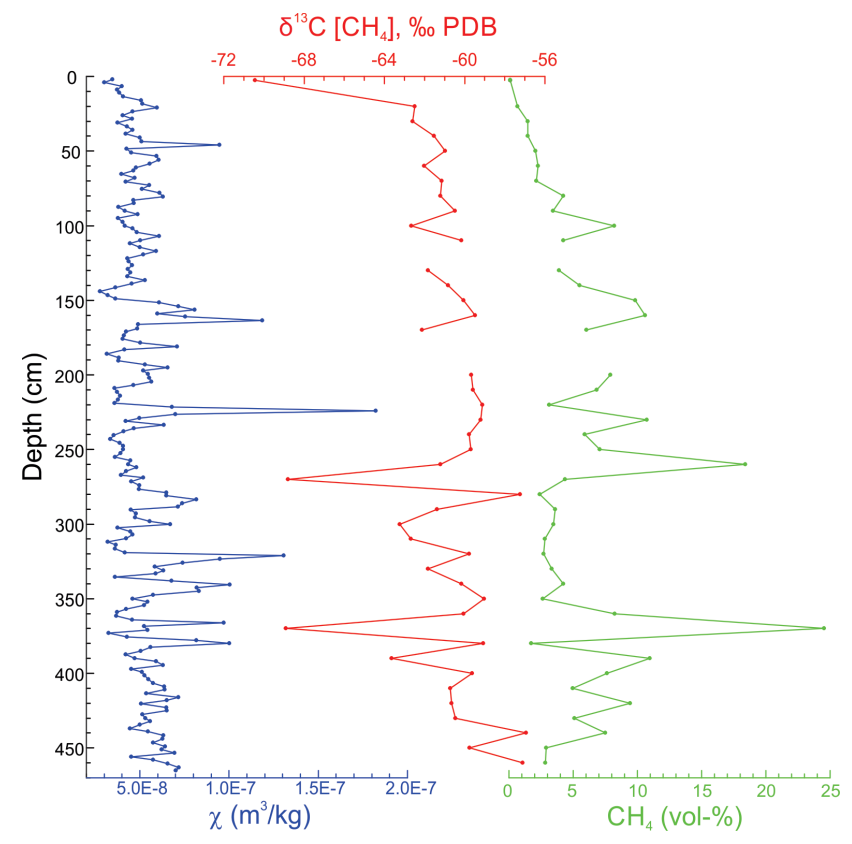

Figure 6. Low-field magnetic susceptibility by mass normalized of sediments and concentration $\mathrm{CH}_{4}$ (vol-\%) and stable carbon isotopes $\delta^{13} \mathrm{C}\left[\mathrm{CH}_{4}\right] \%$ PDB in pore waters of $\mathrm{XC} 05$ sediment core. Data plotted as a function of depth.

isotopes ratio $\left(\delta^{13} \mathrm{C}\right)$ in $\mathrm{CH}_{4}$ varied from -70.4 to -56.9 , pointing to a biogenic origin. More positive values of $\delta^{13} \mathrm{C}$ in $\mathrm{CH}_{4}$ are related to higher magnetic susceptibility, suggesting a relationship between methane oxidation and concentration of magnetic minerals. Intervals with higher $\delta^{13} \mathrm{C}$ in $\mathrm{CH}_{4}$ could be related to oxygen-enriched pore waters, favoring the formation of authigenic iron oxides and increasing magnetic susceptibility. However, additional studies for characterization of magnetic mineral types are necessary to explain the relationship between $\mathrm{CH}_{4}$ oxidation and magnetic susceptibility. Figure 6 shows the $\mathrm{CH}_{4}$ and magnetic susceptibility data obtained for the XC05 core.

\subsection{Palynology and diatom analysis}

Analyses of pollen, spores (plants and algae), diatoms, sedimentary pigment degradation units (SPDU) and charred microparticles will be employed from the Xingu sediments as proxies for the identification of climatic forcing on forest dynamics versus human manipulation of the local vegetation in close interval sampling in the sediments. Diatom analysis in conjunction with SPDU will provide an indirect measurement of former lake levels, as well as determine possible episodes of marine water incursions into the ria system. Changes in river dynamics and vegetation will be studied through a proxy approach applied to the organic particles (charcoal, pollens, spores and diatoms) in sediment cores. Samples for palynological and diatom analysis were collected in intervals of $2 \mathrm{~cm}$. Establishment of vegetation dy- namics as influenced by global patterns of climatic change and local human manipulation of forest elements will also help to trace local surface processes, as they share a common temporal sequence. Lake levels, inferred from diatom and SPDU profiles, will allow for a better understanding of water depth variation in the lake system, and will provide means for a better interpretation of pollen and spore signals in lake sediments. In general, the combination of different biological proxies will permit the evaluation of human impact on the local Late Holocene landscape and the possible occurrence of cultural forests, which in turn may help explain the distribution pattern of Terra Preta de Índio sites in central Amazonia. Pollen analysis and associated biological indicators will result in a high-resolution paleocological record, which is lacking for the Xingu region. Preliminary palynological analyses of cores XC01-2 and XC05 indicate an abundant representation of arboreal taxa such as Cecropia, Cedrela, Cordia, Euphorbiaceae, Genipa, Fabaceae, Lecythidaceae, Mauritia, Melastomataceae, Moraceae, Myrtaceae and Pouteria and herbs belonging to the Cyperaceae and Poaceae families. Typical taxa of open vegetation are found in low percentages and concentration. Regarding diatoms, sediment cores XC01-2 and XC05 present well-preserved frustules with species variation along the core. Core XC01-2 presents at the base (122-98 cm) species of the genus Aulacoseira (A. granulata, A. ambigua, A. granulata var. australiensis), indicating a turbulent water environment. Diatoms are absent between 98 and $70 \mathrm{~cm}$ in depth, suggesting a dry period. Great variability of genera such as Cyclotella, Discostella, Pinnularia, Encyonema, Staurosira, Aulacoseira and Eunotia is observed towards the core top $(68-0 \mathrm{~cm})$. Core XC05 shows diatoms throughout the entire retrieved sediment column, but with little variation among genera, pointing to a more uniform slack water environment. Representatives of the genera Surirella, Diploneis, Aulacoseira, Placoneis, Gomphonema, Encyonema and Eunotia were observed throughout this core.

\subsection{Geochemistry}

A comprehensive suite of geochemical analyses will be applied to sediment cores XC01-2 (floodplain lake site) and XC05 (southern Xingu ria site) in order to infer patterns of environmental change for the Xingu region. Downcore variability in organic and inorganic sedimentary components are commonly paired with biological proxy information (e.g., from pollen, diatoms, benthic invertebrates, and fish fossils) in the study of evolving floodplain lake systems (McGlue et al., 2012; Moreira et al., 2013). Together, these data demonstrate how climate or human activities may influence water levels, hydrochemistry, marine connectivity, and ecological relationships. For cores XC01-2 and XC05, inorganic geochemistry will utilize carbonate coulometry and energy dispersive X-ray fluorescence (XRF) measurements collected at a $2 \mathrm{~cm}$ interval. Considering sedimentation rates expected for the coring sites, the $2 \mathrm{~cm}$ sampling interval is sufficient 
to capture transitions in depositional processes that may be responding to natural or human modification of the surrounding land surface in the decadal to millennial timescales. XRF provides both major and trace element sediment chemistry, which allows a robust mineralogical model to be constructed and potentially affords new insights into dynamic Holocene limnological processes. Organic geochemistry will focus on elemental analysis and stable isotopes of carbon and nitrogen, which will be used to deduce trends in primary productivity, organic matter preservation, and provenance. The synthetic multi-proxy approach we have adopted will greatly expand paleo-record development for the region, which may hold promise for predicting the response of this unique aquatic ecosystem to future disturbances (Gell and Reid, 2014).

\section{Future activities}

A workshop is planned for 2016 to integrate and discuss results of environmental proxies in core sediments, cosmogenic nuclides, thermochronology data, greenhouse gases, and geological correlations with fish diversity. In addition to its unique ecological-landscape character, the Volta Grande do Xingu is also the first clearwater river threatened by the new round of hydropower expansion in the Brazilian Amazon. Thus, lessons from the Volta Grande act as a reference for evaluation of hydropower projects planned for other analogous rivers like the Tapajós River. Environmental impacts of the Belo Monte dams on the Volta Grande were evaluated based on sedimentation data for short time intervals (a few years), considering the size and complexity of the ecological system. Understanding past changes in hydrology, sedimentation and vegetation in decadal to millennial timescales will support more reliable predictions of future ecological scenarios. The major challenge of the project that will be addressed in the workshop is the integration among studies dealing with different timescales, from the geological evolution of the Volta Grande and its role in fish diversity to modern and future influence of anthropogenic activities on river substrates and GHG emissions. To extend the age of environmental reconstructions, future drilling to obtain deep sediment cores in the Xingu ria system will be discussed. Researchers and students interested in the Xingu project are welcome to join the workshop.

Author contributions. H. O. Sawakuchi and D. J. Bertassoli performed greenhouse gas sampling and analyses. J. L. Antinao contributed to rock and sediment sampling for cosmogenic nuclides analyses and is performing analysis of ${ }^{10} \mathrm{Be}$. M. Parra contributed to riverbed rock sampling and thermochronology analysis. L. M. Sousa and M. H. Sabaj Pérez contributed to fish collection and characterization of fish diversity and river substrate. P. E. Oliveira, R. A. Santos and V. B. Medeiros are contributing to palynology analysis and core description. G. A. Hartmann and J. F. Savian are contributing to magnetic analysis and ${ }^{14} \mathrm{C}$ dating. F. N. Pupim and
C. H. Grohmann are contributing to geomorphological analysis and maps. F. N. Pupim and A. O. Sawakuchi are contributing to OSL dating. D. C. Bicudo and S. B. Faustino are contributing to diatom analysis. M. McGlue is contributing to geochemical analysis (XRF, C and N). A. O. Sawakuchi and G. A. Hartmann organized the coring collection and organized the writing of the manuscript, with contributions of all authors.

Acknowledgements. We are very grateful for the outstanding support of divers Dani and Ronca, boat pilots Tonho and Nelson and cook Ilma during the field surveys. We thank the Editor Thomas Wiersberg and the reviewers, Antje Schwalb and Hella Wittmann-Oelze, for comments that substantially improved this paper. A. O. Sawakuchi thanks the FAPESP (grant no. 2011/066091). G. A. Hartmann thanks CAPES (grant AUXPE 2043/2014) and CNPq (grant 454609/2014-0). F. N. Pupim thanks FAPESP (grant no. 2014/23334-4). C. H. Grohmann is a research fellow of CNPq (306294/2012-5) and is co-funded by a collaborative Dimensions of Biodiversity BIOTA grant supported by grant no. 2012/50260-6, São Paulo Research Foundation (FAPESP), the National Science Foundation (NSF DEB-1241066), and the National Aeronautics and Space Administration (NASA). M. Sabaj Pérez and fieldwork were supported in part by the iXingu project, NSF DEB-1257813. J. F. Savian thanks CNPq (grant 457802/2014-6) and FAPERGS (grant 2329-2551/14-1).

Edited by: T. Wiersberg

Reviewed by: A. Schwalb and H. Wittmann-Oelze

\section{References}

Acselrad, H., Antonaz, D., Baines, S. G., Birindelli, J. L. O., Buckup, P. A., Castro, E., Couto, R. C. S., Cunha, M. A. F., Fearnside, P. M., Gorayeb, I., Hernández, F. M., Lima, F. C. T., Magalhães, A. C., Magalhães, S. B., Marin, R. A., Medeiros, H. F., Mello, C. C. A., Molina, J., Ravena, N., Santos, G. M., Silva, J. M., Sevá Filho, A. O., Sousa Júnior, W. C., and Vainer, C. B.: Painel de Especialistas: Análise Crítica do Estudo de Impacto Ambiental do Aproveitamento Hidrelétrico de Belo Monte, Organizado por Sônia Maria Simões Barbosa Magalhães Santos e Francisco del Moral Hernandez, Belém, 29 Outubro 2009, 230 pp., 2009.

Almeida, R. M., Barros, N., Cole, J. J., Tranvik, L., and Roland, T.: CORRESPONDENCE: Emissions from Amazonian dams, Nature Climate Change, 3, p. 1005, doi:10.1038/nclimate2049, 2013.

Bahia, R. B. C., Faraco, M. T. L., Monteiro, M. A. S., and Oliveira, M. A. O.: Folha SA.22-Belém, in: Carta Geológica do Brasil ao Milionésimo. Sistema de Informações Geográficas. Programa Geologia do Brasil, edited by: Schobbenhaus, C., Gonçalves, J.H., Santos, J.O.S., Abram, M. B., Leão Neto, R., Matos, G. M. M., Vidotti, R. M., Ramos, M. A. B., and Jesus, J. D. A. de, CPRM, Brasilia, CD-ROM, 2004.

Bush, M. B., McMichael, C., Raczka, M. F., Toledo, M. B., Power, M. J., Mayle, F. E., and de Oliveira, P. E.: The Holocene of the Amazon, in: Paleoclimas - Série Paleontologia: Cenários de Vida, Ed: Interciência, 5, 369-385, 2014. 
Camargo, M. and Ghilardi Jr., R.: Entre a terra, as águas e os pescadores do médio rio Xingu: uma abordagem ecológica, Belém, PA, 329 pp., 2009.

Camargo, M., Giarrizzo, T., and Isaac, V.: Review of the geographic distribution of fish fauna of the Xingu River Basin, Brazil, Ecotropica, 10, 123-147, 2004.

Dearing, J. A., Dann, R. J. L., Hay, K., Lees, J. A., Loveland, P. J., Maher, B. A., and O'Grady, K.: Frequency-dependent susceptibility measurements of environmental materials, Geophys. J. Int., 124, 228-240, 1996.

Evans, M. E. and Heller, F.: Environmental Magnetism: Principles and Applications of Enviromagnetics, Academic, San Diego, California, 299 pp., 2003.

Farr, T. G., Rosen, P. A., Caro, E., Crippen, R., Duren, R., Hensley, S., Kobrick, M., Paller, M., Rodriguez, E., Roth, L., Seal, D., Shaffer, S., Shimada, J., Umland, J., Werner, M., Oskin, M., Burbank, D., and Alsdorf, D.: The shuttle radar topography mission, Rev. Geophys., 45, RG2004, doi:10.1029/2005RG000183, 2007.

Fearnside, P. M.: Dams in the Amazon: Belo Monte and Brazil's hydroelectric development of the Xingu River Basin, Environ. Manage, 38, 16-27, 2006.

Fujioka, T., Fink, D., Nanson, G., Mifsud, C., and Wende, R.: Flood-flipped boulders: In-situ cosmogenic nuclide modeling of flood deposits in the monsoon tropics of Australia, Geology, 45, 43-46, 2015.

Galbraith, R. F., Roberts, R. G., Laslett, G. M., Yoshida, H., and Olley, J. M.: Optical dating of single and multiple grains of quartz from Jinmium rock shelter, northern Australia: part I, experimental design and statistical models, Archaeometry, 41, 339-364, 1999.

Gell, P. and Reid, M.: Assessing change in floodplain wetland condition in the Murray Darling Basin, Australia, Anthropocene, 8, 39-45, 2014.

Grohmann, C. H.: Morphometric analysis in Geographic Information Systems: applications of free software GRASS and R, Computers \& Geosciences, 30, 1055-1067, 2004

Grohmann, C. H., Riccomini, C., and Alves, F. M.: SRTM-based morphotectonic analysis of the Pocos de Caldas Alkaline Massif, southeastern Brazil, Computers \& Geosciences, 33, 10-19, 2007.

Heckenberger, M. J., Kuikuro, A., Kuikuro, U. T., Russell, J. C., Schimidt, M., Fausto, C., and Franchetto, B.: Amazonia 1492: Pristine Forest or Cultural Parkland?, Science, 301, 1710-1714, doi:10.1126/science.1086112, 2003.

Heyman, J.: Paleoglaciation of the Tibetan Plateau and surrounding mountains based on exposure ages and ELA depression estimates, Quaternary Sci. Rev., 91, 30-41, 2014.

Hippe, K., Ivy-Ochs, S., Kober, F., Zasadni, J., Wieler, R., Wacker, L., Kubik, P. W., and Schlüchter, C.: Chronology of Lateglacial ice flow reorganization and deglaciation in the Gotthard Pass area, Central Swiss Alps, based on cosmogenic 10Be and in situ 14C, Quat. Geochronol., 19, 14-26, 2014.

Kohl, C. P. and Nishiizumi, K.: Chemical isolation of quartz for measurement of in situ-produced cosmogenic nuclides, Geochim. Cosmochim. Ac., 56, 3583-3587, 1992.

Lal, D.: Cosmic ray labeling of erosion surfaces; in situ nuclide production rates and erosion models, Earth Planet. Sc. Lett., 104, 424-439, 1991.

McGlue, M. M., Silva, A., Zani, H., Corradini, F. A., Parolin, M., Abel, E., Cohen, A. S., Assine, M. L., Ellis, G. S., Trees, M. A.,
Kuerten, S., Gradella, F., and Rasbold, G. G.: Lacustrine records of Holocene flood pulse dynamics in the Upper Paraguay River watershed (Pantanal wetlands, Brazil), Quaternary Res., 78, 285 294, 2012.

McMichael, C., Piperno, D. R., Bush, M. B., Silman, M. R., Zimmerman, A. R., Raczka, M. F., and Lobato, L. C.: Sparse preColumbian human habitation in western Amazonia, Science, 336, 1429-1431, 2012a.

McMichael, C., Bush, M. B., Piperno, D., Silman, M. R., Zimmerman, A. R., and Anderson, C.: Scales of pre-Columbian disturbance associated with western Amazonian lakes, The Holocene, 22, 131-141, 2012b.

Moreira, L. S., Moreira-Turcq, P., Turcq, B., Cordeiro, R. C., Kim, J.-H., Caquineau, S., Magloire, M.-Y., Macario, K. D., and Sinninghe-Damsté, J. S.: Palaeohydrological controls on sedimentary organic matter in an Amazon floodplain lake, Lake Maracá (Brazil) during the late Holocene, The Holocene, 23, 1903-1914, 2013.

Murray, A. S. and Wintle, A. G.: The single aliquot regenerative dose protocol: potential for improvement in reliability, Radiat Meas., 37, 377-381, 2003.

Neu, V., Neill, C., and Krusche, A. V.: Gaseous and fluvial carbon export from an Amazon forest watershed, Biogeochemistry, 105, 133-147, 2011.

Nogueira, C., Buckup, P. A., Menezes, N. A., Oyakawa, O. T., Kasecker, T. P., Ramos Neto, M. B., and Silva, J. M. C. da: Restricted-range fishes and the conservation of Brazilian freshwaters, PLoS ONE, 5, e11390, doi:10.1371/journal.pone.0011390, 2010.

Ometto, J. P., Cimbleris, A. C. P., Santos, M. A., Rosa, L. P., Abe, D., Tundisi, J. G., Stech, J. L., Barros, N., and Roland, F.: Carbon emission as a function of energy generation in hydroelectric reservoirs in Brazilian dry tropical biome, Energ. Policy, 58, 109-116, 2013.

Sabaj Pérez, M.: Where the Xingu Bends and Will Soon Break, Am. Sci., 103, 395-403, doi:10.1511/2015.117.395, 2015.

Sawakuchi, H. O., Bastviken, D., Sawakuchi, A. O., Krusche, A. V., Ballester, M. V. R., and Richey, J.: Methane emissions from Amazonian Rivers and their contribution to the global methane budget, Glob. Change Biol., 20, 2829-2840, doi:10.1111/gcb.12646, 2014.

Silva, F. A. and Rebellato, L.: Use space and formation of Terra Preta: the Asurini do Xingu case study, in: Amazonian dark earths: explorations in space and time, edited by: Lehmann, J., Kern, D., Galser, B., and Woods, W. I., New York, Springer, 159168, 2003.

Sioli, H.: Amazônia: Fundamentos de Ecologia da Maior Região de Florestas Tropicais, EditoraVozes, Petrópolis, 72 pp. 1985.

Sousa, W. C. and Reid, J. B.: Uncertainties in Amazon hydropower development: Risk scenarios and environmental issues around the Belo Monte dam, Water Alternatives, 3, 249-268, 2010.

Stickler, C. M., Coe, M. T., Costa, M. H., Nepstad, D. C., McGrath, D. G., Dias, L. C. P., Rodrigues, H. O., and Soares-Filho, B. S.: Dependence of hydropower energy generation on forests in the Amazon basin at local and regional scales, P. Natl. Acad. Sci. USA, 110, 9601-9606, 2013.

Stone, J. O.: Air pressure and cosmogenic isotope production, J. Geophys. Res.-Sol. Ea., 105, 23753-23759, 2000. 
Tachikawa, T., Hato, M., Kaku, M., and Iwasaki, A.: Characteristics of ASTER GDEM version 2, Geoscience and Remote Sensing Symposium (IGARSS), 2011 IEEE International, 3657-3660, 2011.

Thompson, R. and Oldfield, F.: Environmental Magnetism, London, Allenand Unwin., doi:10.1007/978-94-011-8036-8, 1986.

von Blanckenburg, F.: The control mechanisms of erosion and weathering at basin scale from cosmogenic nuclides in river sediment, Earth Planet. Sc. Lett., 237, 462-479, 2005.

Wiesenburg, D. A. and Guinasso, N. L.: Equilibrium solubilities of methane, carbon-monoxide, and hydrogen in water and seawater, J. Chem. Eng. Data, 24, 356-360, 1979.
Wittmann, H., von Blanckenburg, F., Maurice, L., Guyot, J.-L., Filizola, N., and Kubik, P. W.: Sediment production and delivery in the Amazon River basin quantified by in situ-produced cosmogenic nuclides and recent river loads, Geol. Soc. Am. Bull., 123, 934-950, 2011.

Wohl, E. E. and Merritt, D. M.: Bedrock channel morphology, Geol. Soc. Am. Bull., 113, 1205-1212, 2001.

Zuanon, J.: História natural da ictiofauna de corredeiras do Rio Xingu, na região de Altamira, Pará, Unpublished Ph.D. dissertation, Instituto de Biologia da Universidade Estadual de Campinas, 183 pp., 1999. 